\title{
THE AUDITION OF FINAL ACCOUNTS LAW: A CRITICAL APPROACH ON THE INEFFICIENCY OF EXISTING AUDITION AND SOLUTION OFFERS IN ORDER TO PROMOTE EFFICIENCY
}

\author{
Zeynep MÜFTÜoĞLU1
}

\begin{abstract}
The detection of flaws in the audit of the final accounts law, which is an indicator of the compatibility of the revenues collected and spending in a given financial year made by the executive body to the budget law, and efforts to address these flaws is a major requirement for fulfilling the principle of the rule of law and ensuring the budget right. In the study, regarding the importance of final accounts law in the realization of rule of law principle and budget right, the characteristics of the final accounts law and the auditing mechanisms on it are being examined. Such examination is held through a critical approach and ineffective and problematic sides of the auditing are tried to be sorted out. In the light of that research, solutions are tried to be developed. Regarding that aim, in the conclusion section, the mechanisms required to address the flaws caused by the shortcomings of the conducted audits will be discussed and suggestions that would remove these shortcomings will tired to be suggested. As it can be seen in the discussions, the most possible and effective way to remove the flaws in the auditing of the final accounts law can be appointed and zoomed on the legislative branch. On the basis of the characteristics of the auditions, solutions will be more focused on legislative level as well.
\end{abstract}

Keywords: Fiscal accounts law, legislative audition, court of accounts, constitutional court, public budget

JEL Code: H00, H61, H83.

\section{Introduction}

The legislative body authorizes the executive body to collect revenues listed in the budget estimates and make spending by approving the budget law. The executive body is expected to use this permission and approval in the same budget year in accordance with the constitution, budget law and other existing regulations and it use must be reviewable (Erginay, 2010: 206). The budget control can be conducted in two main stages; during and after the execution. And the clearest indications concerning the corruption and irregularities can be detected in budget controls conducted after the implementation (Uluatam, 1978: 84). Therefore final accounts law serves as the main audit tool in determining whether the executive body exercised the authority granted to collect revenues and make spending in accordance with the law. Regarding the mentioned importance of the final accounts law, fixing the flaws within the audition of such law is a major necessity. Therefore, this study will examine the existing auditing methods on the final accounts law in our country from a critical point of view. Afterwards attention will tried to be dawn on the aspects that are not covered by these auditing methods. The study will examine the audits conducted on the proposal by the court of accounts and later by the Turkish Grand National Assembly (TGNA) and finally will deal with the nature and the scope of the examination of compatibility to the constitution which might emerge after the proposed law had been legislated.

1 Dr. Res. Asst., Atlım University Faculty of Law, zeynep.muftuoglu@atilim..edu.tr 


\section{Final Accounts Law}

The final accounts law serves as an instrument to demonstrate whether or not the revenues collected and spending made in a given financial year by the executive body are undertaken in accordance with the budget estimates and existing regulations (Mutluer, 2006: 315, 316). Thus, in a sense, the mentioned law would mean the discharge of the budget execution and is an indication and result of the fact that the sovereignty remain at the hands of the nation (Bulutoğlu, 2004: 167). Due to this function and its importance, the law has been safeguarded at the constitutional level as well. Article 161 of the constitution states "Central government final accounts bills shall be submitted to the TGNA by the President of the Republic within six months of the end of the relevant fiscal year... The final accounts bill shall be debated and adopted together with the budget bill of the new fiscal year." While the constitution designates the status of the final accounts law as mentioned above, article 42 of Public Financial Management and Control Law No: $5018^{2}$ (Law No 5018) notes that TGNA "exercises its power of approving the implementation results of the budget law through the final accounts law".

\section{The Auditing of Final Accounts Law}

On the basis of the article 161 of the constitution and article 42 of Law No: 5018, the audit on the final accounts law can be classified as Audit by Court of Accounts and Audit by TGNA. As in all other laws, the final audit that would be carried out on the law in question is the compatibility by the Constitutional Court.

\subsection{Court of Accounts}

Court of Accounts is designated in the article 160 of the constitution and on the basis of this designation the court describes its duties as "auditing, trial, and reporting." The Court of Accounts carries out an auditing and reporting on the proposal of the Final Accounts Law and its operations in this process bears the character of an advice for the TGNA. Article 161 of the Constitution obliges the Court of Accounts to submit its statement of general conformity to the Grand National Assembly of Turkey within seventy-five days of the submission of the final accounts bill. Even though, it is stated in the Constitution that submission of the reports from the court of Accounts to the TGNA does not end the unfinished audition of the court on accounts, such audition does not give rise to any political consequences on the politically liable ones. The Court of Accounts can only opt for not including the data that it does not have in the statement of general conformity, and not issuing a statement of general conformity if it does not view the Final Accounts Bill as appropriate or listing the unlawful deeds in the statement of general conformity report. Even in such a case, there are no designated enforcements regarding the contradictions of the Final Accounts Bill.

\subsection{Turkish Great National Assembly}

As designated in article 161 of the constitution, the Final Accounts Bill has to be submitted to the parliament within six months from the end of the relevant financial year. The Final Accounts

\footnotetext{
25018 sayılı Kamu Mali Yönetimi ve Kontrol Kanunu, R.G. 24. 12. 2003, S. 25326.

3 T.C. Sayıştay Başkanlığı. (2018). Sayıştay'ın Görevleri, https://www.sayistay.gov.tr/tr/?p=2\& Categoryld=73, (28.12.2018).
} 
Bill is initially submitted to the Planning and Budget Commission of the parliament. Prior to the constitutional changes of $2017^{4}$, the composition of the Planning and Budget Commission was specifically designed in the constitution, in the new situation there is no mention of the commission in the constitution. The commission serves as the only platform where the opposition can discuss in detail the revenues collected by the executive body, and detect and discuss in real sense the unlawful deeds such as overspending the unlawful use or transfer of funds or acquiring insufficient or excessive public revenues. This is because after the bill has been sent by the commission to the parliament, it will no longer be possible to examine, detect and discuss its entries one by one due to the busy schedule of the parliament and lack of technical expertise among the members of the parliament. As regulated in the last entry of the article 161 of the constitution, the Final Accounts Bill will be discussed and legislated along with budget proposal for the new year. As a negative result of the political mechanism's nature to focus on the future rather than the past, in practice the Final Accounts Bill almost automatically is approved in the parliamentary counsel. Moreover, no special enforcements are stipulated either in the constitution or the relevant regulations concerning the contradictions in the Final Accounts Bill, even in case such contradictions are detected at the Commission or parliamentary counsel stages.

\subsection{The Constitutional Court}

The power and the duties of the constitutional court are regulated in article 148 of the Constitution. Even though it has characteristics peculiar to itself, the Final Accounts Law is still a law and since in the constitution it is not left outside the scope of the constructional court, it is subject to the audition of the court. The constitutional court's examination of the laws' compatibility with the constitution takes place in two different types, namely annulment or plea. The only form of auditing for the constitutional court on the compatibility of the final accounts law is procedural auditing. As regulated in article 148 of the constitution, this control is limited with verifying whether or not the latest vote has been conducted with the required majority. On the basis of these discussions, it is possible to argue that an effective auditing could not be implemented on the final accounts law concerning its compatibility with the constitution.

\section{Solution Offers in Order to Promote the Efficiency in Auditing System}

In order to realize the requirements of the rule of law principle and the budget right, it is necessary to establishment enforcement mechanisms within the chain of authority-responsibility in case the Final Accounts Law includes unlawful elements. Taking into consideration the advisory nature of the auditing by the Court of Accounts and the inefficiency of the Constitutional Court due to the contents and nature of the Final Accounts Law, it seems appropriate to suggest that the enforcement mechanisms should be strengthened by the legislative auditing.

In order to render the legislative auditing more effective and up to the task, it is necessary to focus on the commission auditing. In order to achieve that it is possible to consider examining the bill in a separate and specialized commission prior to its submission to the Planning and Budget Commission and submitting it to the Planning and Budget Commission to be discussed together with the budget proposal only after it had been examined by this specialized commission.

46771 sayılı Türkiye Cumhuriyeti Anayasasında Değişiklik Yapılmasına Dair Kanun, R. G. 11.02.2017, S. 29976. 
After these, it is necessary to take the required steps to ensure that the Commission's and the Court of Accounts' reports would reach the parliamentary counsel on time and in full. Finally it is urgently necessary to abandon the habit of automatically approving the Financial Accounts Bill in the parliamentary counsel and to discuss the bill in greater detail at the parliamentary counsel. In the present system, in case the bill is rejected in the parliamentary counsel, the only auditing mechanisms available are those traditional auditing methods, designated in article 98 of the Constitution. Yet to the date, these were never implemented against the Final Accounts Law. Under these circumstances, it is not possible to argue that an effective TGNA auditing over the Final Accounts Law is being implemented. Moreover, even if such an auditing is to be implemented, there are no effective enforcements to follow up. Thus, in case an unlawful revenue or expense is detected in the final accounts law, mechanisms to be implemented on the politically liable persons are needed. The improvements in question can placed under constitutional guarantee by including additional entries to the article 161 of the constitution, which regulates the budget law and the final accounts law and this would proportional to the importance the Final Accounts Law carries.

\section{Conclusion}

The Final Accounts Law is an indispensable condition in order for a country to talk of budget right. The failure to conduct an effective auditing over this law can lead to very damaging results in terms of democracy, the rule of law principle, legal certainty and security and budget right.

As discussed in the second part of this study, although there are three types of auditing on the Final Accounts Law are implemented by the Court of Accounts, TGNA, and the Constitutional Court, in reality none of these amount to a real auditing and the auditing's findings lack any enforcement ensuring that the unlawful acts in the budget execution are prevented and that those responsible for these unlawful acts are punished. As discussed in the last section of this study, in order to eliminate these shortcomings, the most appropriate auditing would be the auditing carried out by the legislative body.

\section{References}

\section{Books;}

Erginay, A. (2010). Kamu Maliyesi, Kamu Gelirleri-Kamu Giderleri-Devlet Bütçesi- Kamu Borçları Maliye Politikası, Gözden Geçirilmiş ve İşlenmiş 18. Baskı, Ankara: Savaş Yayınları.

Mutluer, K., Öner, E., Kesik, A. (2018). Bütçe Hukuku, Güncelleştirilmiş 4. Baskı, İstanbul, İstanbul Bilgi Üniversitesi Yayınları.

Bulutoğlu, K. (2004). Kamu Bütçesi Kamu Harcamaları Kamu Borçları, İstanbul: Batı Türkeli Yayıncilık.

Uluatam, Ö. (1978). Kamu Maliyesi, Ankara Üniversitesi Siyasal Bilgiler Fakültesi Yayınları No: 413, Ankara: Ankara Üniversitesi Basımevi. 


\section{Internet Sources;}

Anayasa Mahkemesi Kararları, E. 2015/24, K. 2018/51, RG. 21.06.2018, S. 30590; E. 2014/52, K. 2018/36, RG. 09.11.2018, S. 30590; E. 2015/30, K. 2018, 54, RG. 09.11.2018; E. 2015/7, K. 2016/47, RG. 22.09.2016, S. 29835; E. 2013/24, K. 2013/133, RG. 22.07.2014, S. 29068. http://www.anayasa.gov.tr/icsayfalar/kararlar/kbb.html (28.12.2018)

T.C. Sayıştay Başkanlığı. (2018). Sayıştay'ın Görevleri, https://www.sayistay.gov. tr/ $\operatorname{tr} /$ ?p=2\&Categoryld=73, (28.12.2018) 